\title{
PEMETAAN BAHAYA LONGSORAN BERDASARKAN KLASIFIKASI STATISTIK PEUBAH TUNGGAL MENGGUNAKAN SIG: STUDI KASUS DAERAH CIAWI-PUNCAK-PACET, JAWA-BARAT
}

\author{
Landslide Hazard Mapping based on GIS Univariate Statistical Classification: \\ Case Study of Ciawi-Puncak-Pacet Regions, West Java
}

\author{
Baba Barus \\ Laboratorium Penginderaan Jauh dan Kartografi, \\ Jurusan Tanah, Fakultas Pertanian, Institut Pertanian Bogor \\ JI. Raya Pajajaran 1, Bogor 16144
}

\begin{abstract}
Regarding environmental degradation in Puncak and its surrounding area due to the rapid landuse changes during 1981-1994, some mitigation schemes for soil erosion have been implemented but landslides. Data on landslide and its causative factors (landuse, soil, geology, slope, climate, and terrain mapping unit) and their relationships in the area are still not available. The objective of this research is to develop method and procedure to map landslide hazard by using GIS (Geographical Information System) univariate-statistical analysis applied on the area as a case study. For this purpose, three methods to classify and to map landslide hazard were evaluated. They were respectively developed by considering: (a) unweighted density total number of landslide, Method\#1, (b) density total number, weighting value, and age of landslide, Method\#2, and (c) density total number, weighting value, age, and activity level of landslide, Method\#3. The density number is counted by overlying each of the landslide maps and each of the causative factors maps used, and from this step the weighting value is derived. The resulting density number of landslide given as cumulative percentage and the corresponding weighting value were then plotted on an $X-Y$ graph. From the graph, the level of landslide hazard is classified by applying: (1) standard classification procedure as the default statistical analysis given by the software used, and (2) natural classification procedure as it based on the nature of the curve slope of the cummulative graphic. The result given by the three methods were varied but in general they gave landslide hazard map with a similar pattern in which the very high and very low hazard level in the study area increased during the period of 19811994. Of the three methods, applying the natural classification gave a better result than that of the standard classification procedure. Method\#2 and Method\#3 were better than Method\#1 in predicting the future landslide occurence. Apparently, Method\#3 should show the best result but the effect of conversion from raster to vector data in GIS significantly reduced the quality of the resulting map.
\end{abstract}

Key-words: GIS, statistical univariate analysis, landslide, landslide causative factors, weighting value, standard classification, and natural classification.

\section{PENDAHULUAN}

Dampak perubahan penggunaan lahan yang sangat cepat di kawasan Puncak dan sekitarnya selama 10 tahun terakhir terhadap kelestarian lingkungan semakin nyata. Hal ini antara lain ditunjukkan oleh peningkatan suhu udara di kawasan Bogor, fluktuasi aliran sungai Ciliwung yang tinggi dan keruhnya sungai- sungai yang bermuara di wilayah ini. Salah satu akibat perubahan ini adalah terjadinya gerakan tanah, khususnya longsoran dangkal (shallow landslide). Gerakan tanah berkaitan langsung dengan berbagai sifat fisik alami seperti: struktur geologi, bahan induk, tanah, pola drainase, lereng/bentuk lahan, hujan maupun sifat-sifat non-alami yang bersifat dinamis seperti penggunaan lahan dan infra-struktur.

Barus, B. 1999. Pemetaan bahaya longsoran berdasarkan klasifikasi statistik peubah-tunggal menggunakan SIG: Studi kasus daerah Ciawi-Puncak-Pacet, Jawa Barat. J.ll.Tan.Lingk. 2(1):7-16. 
Kegiatan studi longsoran selama ini lebih banyak ditangani oleh kelompok insinyur mekanika tanah. Studi yang dilakukan terutama ditujukan sebagai dasar tindakan kuratif setelah muncul kejadian longsoran dan kajiannya sangat bersifat lokal. Kajian yang bersifat kewilayahan (pemetaan) telah mulai dilakukan oleh kelompok geologi lingkungan yang mencoba menyusun zonasi wilayah berpotensi longsor. Tetapi, secara umum kajiannya juga masih lebih banyak menekankan penggunaan pendekatan geologi dan belum melibatkan ahli vegetasi atau tanah dalam memahaminya.

Longsoran di wilayah Puncak dan sekitarnya umumnya bersifat dangkal (2-5 meter), bertipe debris avalance dan/atau rotational slump. Tipe debris biasanya terjadi di daerah curam, sedangkan tipe slump di daerah lebih landai dan lebih dipengaruhi oleh perkembangan sifat tanah dan pola penggunaan lahan di atasnya.

Dari hasil penelitian longsoran di daerah tropis, Varnes (1984) dan Gupta (1993) menemukan hubungan antara longsoran dan tingkat perkembangan tanah. Mereka menyimpulkan bahwa sebagian besar bidang luncur longsoran dijumpai di horizon atau lapisan B, selain di antara lapisan C dan R (rock). Di Amerika, Sidle, Pearce dan O'Loughlin (1985) serta Greenway (1987) telah melakukan penelitian tentang penanggulangan longsoran yang dikaitkan dengan tipe vegetasi. Mereka berhasil menemukan hubungan antara spesies tanaman dengan tipe longsor tertentu dan merekomendasikan berbagai spesies tumbuhan untuk penanggulangan longsoran.

Sistem Informasi Geografis (SIG) sebagai sarana untuk menyimpan, menggali dan memanipulasi data serta menghasilkan produk (Aronoff, 1993) banyak dimanfaatkan dalam berbagai studi dan kegiatan pengelolaan sumberdaya lahan maupun pemetaan bahaya longsoran (Rengers dan Soeters, 1993). Kelebihan SIG terutama berkaitan dengan kemampuannya dalam menggabungkan berbagai data yang berbeda struktur, format dan tingkat ketepatan (Lillesand dan Kiefer, 1994), sehingga memungkinkan integrasi berbagai disiplin keilmuan, yang sangat diperlukan dalam pemahaman fenomena bahaya longsoran, dapat dilakukan dengan lebih cepat.

Salah satu kemudahan utama penggunaan SIG dalam pemetaan bahaya longsoran adalah kemampuannya dalam menumpang-tindihkan longsoran dalam unit peta tertentu sehingga dapat dianalisis secara kuantitatif. Analisis ini antara lain dapat dilakukan dengan pendekatan: geomorfologik, deterministik, penyebaran longsoran, multivariate dll. Analisis peubah tunggal (univariate analysis) merupakan salah satu pendekatan secara statistik dalam pemetaan bahaya longsoran yang didasarkan pada kerapatan jumlah atau aktivitas longsoran per satuan peta.

Penelitian ini bertujuan mengembangkan dan mengevaluasi tiga metode klasifikasi penentuan kelas bahaya longsoran dan pemetaannya berdasarkan pendekatan statistik univariate analysis dalam SIG dengan modifikasi parameter peta longsoran dan parameter pembentuknya, yang dimulai dari sistem penentuan bobot unit kelas hingga penentuan batas klasifikasi.

\section{BAHAN DAN METODE}

\section{Daerah Penelitian, Bahan dan Alat}

Daerah penelitian meliputi wilayah CiawiPuncak-Pacet, Jawa Barat, sekitar 70 km dari Jakarta, yang merupakan bagian hulu DAS Ciliwung (Gb. 1). Bahan yang digunakan terdiri dari: foto udara 1981 dan 1993 (skala $1: 50.000)$, peta topografi $(1: 50.000)$, peta geologi $(1: 250.000)$, peta tanah $(1: 50.000)$ dan citra SPOT. Pengolahan data dilakukan dengan bantuan perangkat lunak SIG-ILWIS, Lotus dan GeoSTAT.

\section{Metode}

Penelitian ini terdiri dari 3 tahapan kerja yaitu: (1) interpretasi foto udara dan citra SPOT serta kompilasi data sekunder, (2) pengamatan lapang untuk mengecek hasil interpretasi longsoran dan penggunaan lahan, serta (3) pemetaan bahaya longsoran dengan SIG. Dalam studi ini, pemetaan tidak ditujukan untuk kepentingan kartografi, tetapi untuk pengembangan sistem klasifikasi dan pemetaan hasilnya.

Interpretasi foto udara ditujukan untuk inventarisasi longsoran dan penggunaan lahan pada tahun 1981 dan 1993. Citra SPOT dianalisis secara digital untuk mempertajam kenampakan sudut dan selanjutnya dilakukan interpretasi lineament features melalui hardcopy. Data sekunder diproses untuk memperoleh peta geologi dan peta tanah. Peta sungai diturunkan dari peta topografi dan hasil interpretasi. 


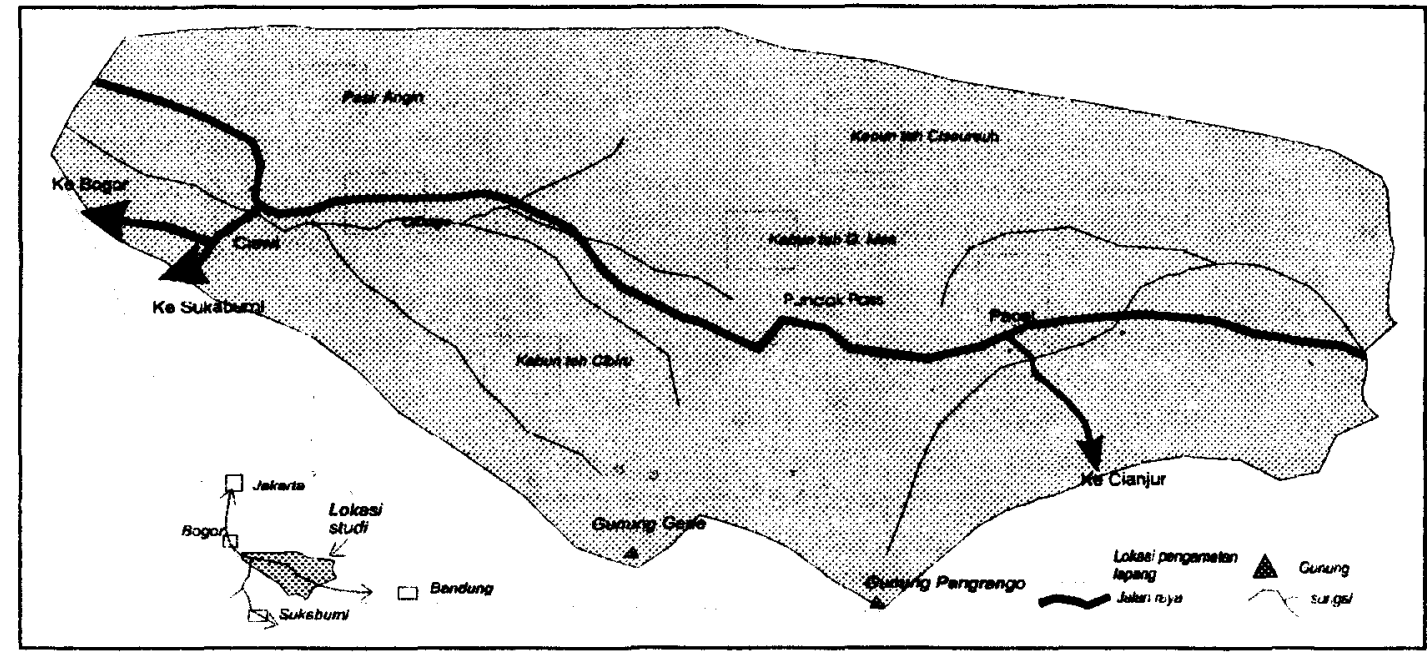

Gambar 1. Lokasi daerah penelitian

Dalam pengamatan lapang dilakukan pengukuran kedalaman, umur, panjang dan bidang luncur longsoran serta aspek lain yang berkaitan dengan penggunaan lahan.

Pemetaan diawali dengan pendigitasian peta longsoran (longsoran lama pra-1981, longsoran baru pra-1981 dan longsoran baru pra-1993), peta bentuk lahan, peta tanah, peta geologi, peta lineament, peta drainase dan peta topografi. Peta lineament, drainase dan topografi dibangkitkan dalam SIG. Selanjutnya dilakukan analisis hubungan antar peta longsoran dengan peta setiap faktor pembentuknya. Dengan cara overlay dihitung kerapatan longsoran per unit peta sebagai dasar penetapan nilai pembobot untuk setiap satuan peta. Selanjutnya nilai pembobot setiap unit peta dijumlahkan untuk memperoleh nilai total akhir. Dari nilai ini kemudian disusun grafik persentasi kumulatif sebagai dasar penetapan kelas bahaya longsoran (Gb. 2).

Perhitungan kerapatan longsoran per unit peta faktor dilakukan sebagai berikut:

$$
D_{\text {jumlan }}=\frac{1.10^{6}}{\operatorname{Area}\left(X_{i}\right)} \text { Jumlah }(S x i)
$$

dimana: Djumlah $=$ kerapatan $\left(\right.$ jumlah $\left./ \mathrm{km}^{2}\right)$; Area $(X i)=$ luas area dalam $\mathrm{m}^{2}$ dari peubah kelas $\mathrm{Xi}$; Jumlah $(\mathrm{Sxi})=$ jumlah longsoran dalam peubah kelas $X i$; Nilai $10^{6}$ dipakai untuk mengkonversi nilai $\mathrm{m}^{2} \mathrm{ke} \mathrm{km}^{2}$.

Pemetaan dilakukan dengan 3 cara yang dibedakan dari cara pengelompokan umur dan aktivitas longsoran serta pembobotan untuk setiap kelompok longsoran. Cara1 tidak memperhitungkan tingkat aktivitas dan hanya didasarkan pada jumlah longsoran per satuan unit peta faktor penyebab, Cara2 memasukkan umur longsoran dan penambahan nilai pembobot dan Cara3 memasukkan umur dan tingkat aktivitas longsoran serta penambahan nilai pembobot.

Pembobotan dilakukan dengan memberikan nilai terbesar untuk longsoran yang masih aktif. Semakin tua longsoran maka semakin kecil nilainya. $\mathrm{Hal}$ ini dilakukan dengan pertimbangan bahwa umumnya longsoran aktif berpotensi menyebabkan longsoran lanjutan karena adanya pengaruh lingkungan di daerah longsoran, khususnya pada bagian puncak (srown), yang dapat melemahkan shearftensil strength atau menyebabkan masuknya air sehingga akan melemahkan kestabilan tanah dan mendorong terjadinya tanah lepas (Varnes, 1994). Rincian pembobotan selengkapnya disajikan pada Tabel 1.

Tabel 1. Nilai pembobotan longsoran berdasarkan aktivitasnya pada berbagai periode

\begin{tabular}{ccccc}
\hline & \multicolumn{4}{c}{ Peta longsoran 1994 } \\
\cline { 3 - 5 } & \multicolumn{1}{c}{ Tidak ada longsoran } & Longsor tidak aktif & Longsor aktif \\
\hline Peta longsoran 1981 & 0 & Keaktifan longsoran & \\
Tidak ada longsoran & 0 & 0 & 1.8 \\
Longsor tidak aktif & 0 & 1 & 1.8 \\
Longsor aktif & 0 & 1.4 & 1.8 \\
\hline
\end{tabular}




\section{Cara1}

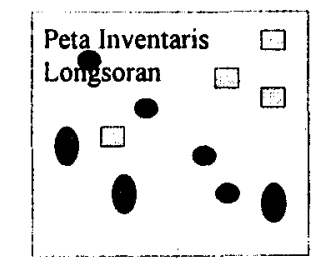

"Cross"

\section{Cara2}

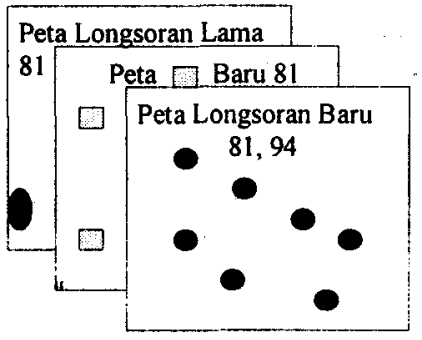

Cara3

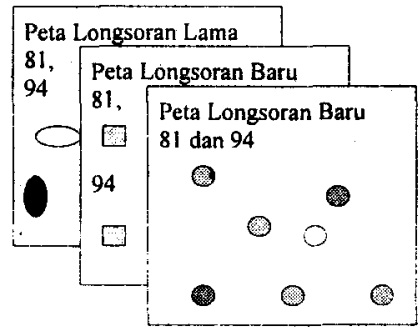

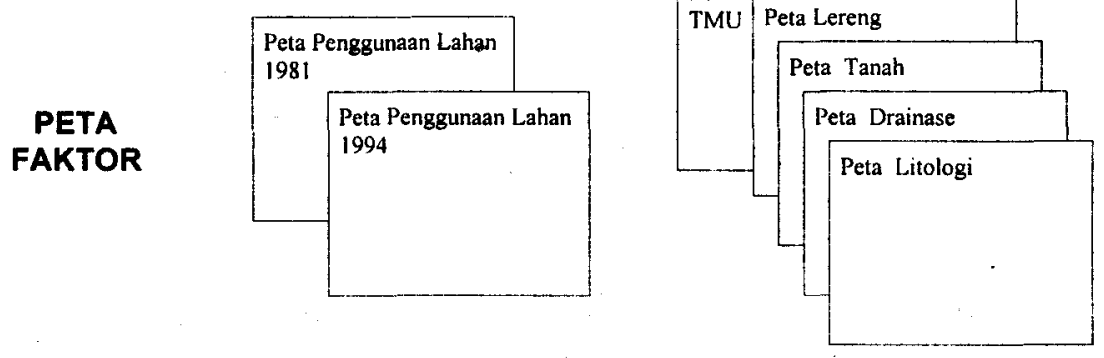

Bobot Nilai $=$ Kerapatan unit per faktor - Kerapatan per peta Tambahan bobot nilai diberikan pada peta utama pada Cara\#2 \& Cara\#3

Peta Akhir = penjumlahan nilai terbobot dari semua peta faktor

Nilai akhir terbobot untuk diklasifikasikan pada kurva grafik kumulatif

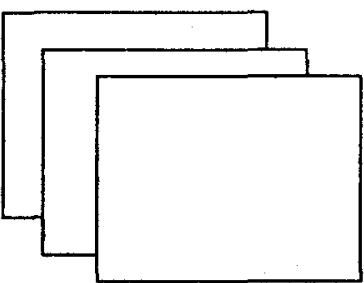

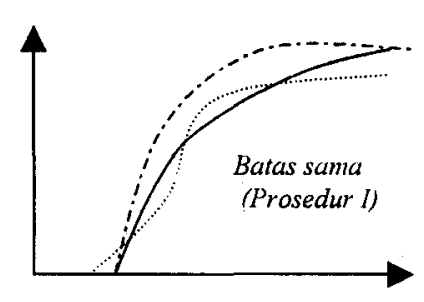
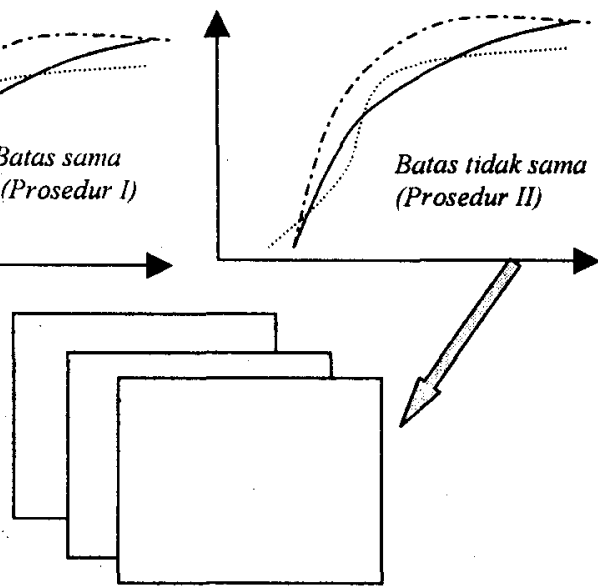

PETA BAHAYA LONGSORAN

\section{HASIL DAN PEMBAHASAN}

Hubungan antara Bentuk Lahan, Lereng, Bahan Induk, Tanah, Pola Drainase dan Proses Struktural dengan Longsoran

Unit bentuk lahan (TMU) mempunyai kelas paling banyak sehingga memiliki variasi nilai pembobot (kerapatan longsoran) paling besar. Secara umum, nilai kerapatan longsoran pada unit peta bentuk lahan lebih tinggi dibandingkan faktor lain. Hal ini menunjukkan bahwa pengelompokan unit berdasarkan bentuk lahan berpengaruh paling nyata terhadap variasi kemunculan longsor. Hal ini terjadi karena variasi TMU untuk penelitian ini dapat dilakukan 
dengan lebih detil dan terkontrol. Terrain yang paling tinggi kerapatan longsornya adalah kakilereng bergelombang yang tertoreh moderat dan yang tertoreh kuat, dataran volkan pada lereng atas, serta sisi lereng lembah dan punggung vulkanik. Longsoran tipe debris avalance umumnya terjadi di lereng curam, sedangkan tipe rotationalslump umumnya muncul di lereng landai-curam.

Hubungan longsoran dengan litologi terlihat jelas. Bahan sedimen tersier dari kombinasi pasir dan liat memberikan intensitas longsoran paling tinggi, diikuti oleh bahan piroklastik lepas. Di daerah penelitian, kerentanan batuan shale-clay terhadap longsoran tidak terbukti. Hal ini diduga dipengaruhi oleh cara pengelolaan lahan. Longsoran pada tanah dengan batuan induk marl-clay dijumpai relatif sedikit. Hal ini tidak sesuai dengan kenyataan yang banyak terjadi dan diduga berkaitan dengan pola penggunaan lahan di atasnya yang didominasi oleh hutan.

Tingkat perkembangan tanah berpengaruh nyata terhadap longsoran. Tanah sudah berkembang atau berkembang seperti Typic Hapludults dan Typic Hapludalfs memberikan kerapatan longsoran tertinggi, sedangkan pada tanah muda relatif sedikit dijumpai longsoran. Bidang luncur longsoran umumnya tedapat di lapisan B dan/atau antara lapisan C dan R.

Hubungan antara longsoran dengan aliran sungai hanya ditemukan pada orde 1. Pada aliran kecil tidak ditemukan hubungan ini. Pengaruh aliran dalam mengerosi dasar sungai dan sisi lereng (lembah) berperan besar dalam mengurangi kestabilan lereng. Umumnya di sepanjang jalur sungai terjadi longsoran tipe debris avalance.

\section{Hubungan Longsoran dengan \\ Penggunaan Lahan dan Perubahannya}

Berdasarkan hasil pengamatan tahun 1981 sampai 1994 diketahui bahwa longsoran cenderung terjadi pada beberapa tipe penggunaan lahan, yaitu: pertanian lahan kering dengan sistem konservasi yang tidak baik, lahan kering campuran dengan sistem konservasi yang baik dan tidak baik, perkebunan teh yang tidak dikelola dengan baik, hutan sekunder dan belukar. Wilayah dengan sistem konservasi yang tidak baik secara umum lerengnya tidak stabil. Longsoran terjadi jika daya tahan lereng lebih rendah dari daya dorong tubuh tanah karena terbentuknya bidang luncur yang dapat melemahkan kestabilan lereng. Seringnya terjadi longsoran pada lahan yang tertutup belukar dan hutan sekunder belum dipahami sepenuhnya, dan diduga berkaitan dengan faktor lain yang lebih berperan.

Terjadinya longsoran pada perkebunan teh berkaitan dengan kurang kuatnya akar tanaman menahan secara total daya dorong tubuh tanah. Dari pengamatan lapang diketahui kedalaman perakaran tanaman teh umumnya \pm 50-70 cm, dimana di bawahnya terdapat lapisan B atau dekat ke lapisan C. Fenomena ini juga dijumpai pada kejadian kemunculan longsoran 'baru' pada tahun 1981 dan 1994 dengan nilai kerapatan longsoran yang meningkat secara nyata, masing-masing dari 1.05 menjadi 4.04 .

Perubahan penggunaan lahan juga berpengaruh nyata terhadap kejadian longsoran. Longsoran pada periode 1981-1994 terutama terjadi akibat perubahan penutupan lahan dari hutan primer dan semak belukar menjadi kebun teh yang tidak dikelola secara baik serta dari semak belukar, sawah dan hutan primer menjadi lahan kering yang tidak dikelola dengan baik. Perubahan ini secara nyata juga menyebabkan perubahan sifat fisik tanah yang lebih lanjut akan mempengaruhi kestabilan lereng sehingga adanya faktor eksternal seperti hujan dapat mempercepat terjadinya longsoran.

\section{Perbandingan Cara Pemetaan}

Secara umum pemetaan dengan Cara1 meningkatkan nilai kerapatan longsoran per satuan peta dari peta individu (map factor), baik untuk peta tahun 1981 maupun 1994. Nilai kerapatan ini juga meningkat dari tahun 1981 ke 1994, dimana penggunaan Cara2 memberikan nilai peningkatan yang paling jelas. Pembobotan berdasarkan perbedaan umur longsoran jelas mempengaruhi nilai yang dipakai dalam peta digital.

Cara3 idealnya memberikan hasil yang juga nyata, tetapi dalam penelitian ini hasilnya tidak berbeda nyata dengan Cara1. Hal ini disebabkan oleh efek konversi dari data raster ke vektor yang mengakibatkan penurunan ukuran unit longsoran meskipun jumlahnya masih sama. Ukuran longsoran yang kecil jika dipotongkan dengan peta faktor akan hilang dalam perhitungan individu longsor dalam SIG. Penyusunan database yang benar akan dapat mengatasi kendala ini. 

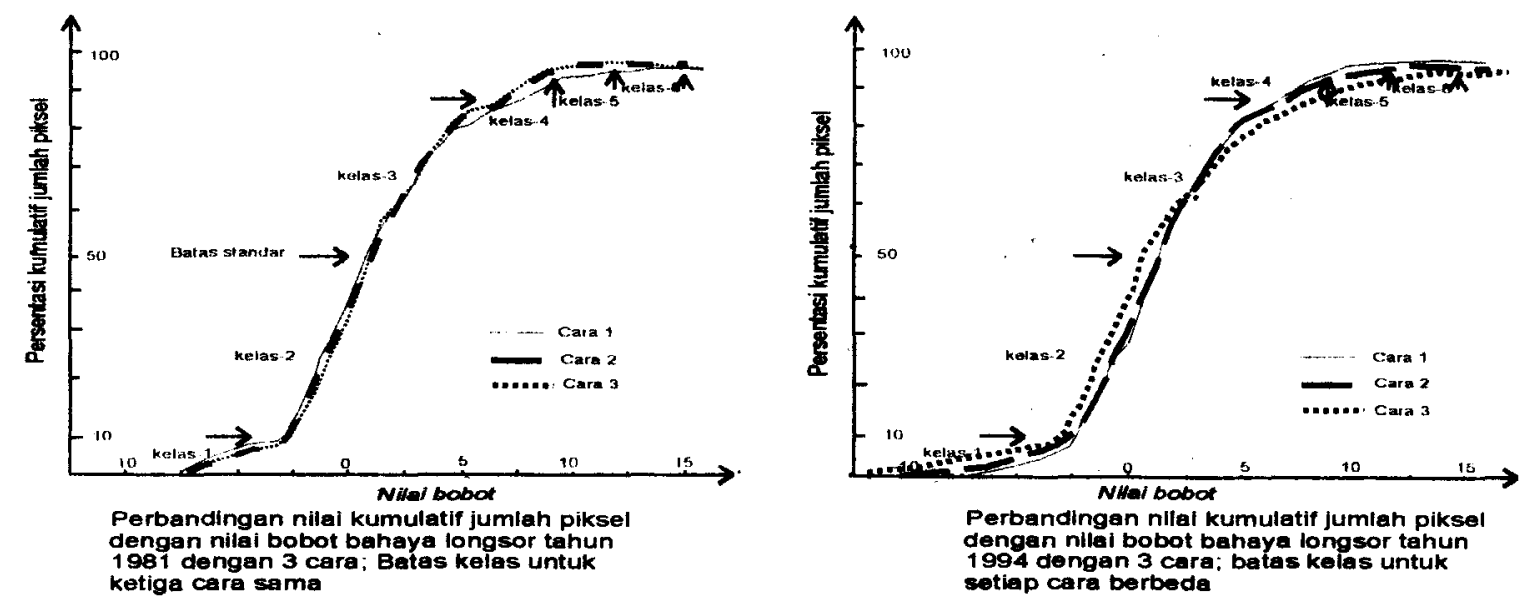

Gambar 3. Grafik kumulatif nilai hasil pemetaan dengan cara dan tahun berbeda

\section{Analisis Grafik Kumulatif untuk Klasifikasi Pemetaan}

Gambar 3 memperlihatkan grafik kumulatif kejadian longsoran menggunakan ketiga cara pemetaan pada tahun yang berbeda (1981 dan 1994).

Perbedaan hasil terutama terlihat pada bagian bawah dan bagian atas grafik. Artinya, perbedaan terutama didapat pada bagian dengan kelas bahaya rendah dan kelas bahaya tinggi. Grafik tersebut juga menunjukkan bahwa Cara1 dan Cara3 memberikan kesamaan hasil yang lebih tinggi. Secara keseluruhan, ketiga metode memberikan jumlah daerah bahaya yang semakin besar dengan meningkatnya nilai pembobot, dimana Cara2 memberikan nilai terbesar.

\section{Hasil Pemetaan Bahaya Longsoran dan Pemantauannya}

Pembatasan kelas bahaya longsoran dilakukan dengan dua prosedur, yaitu: (1) prosedur standar, dimana penarikan batas kelas dilakukan secara otomatis untuk setiap cara dan tahun yang berbeda sesuai perangkat lunak statistik yang digunakan dan (2) prosedur alami, dimana batas kelas ditentukan berdasarkan kenampakan grafik. Hasil pemetaan menurut ketiga cara disajikan pada Gambar Lampiran 1 dan 2.

Untuk ketiga cara pemetaan, penggunaan prosedur standar menghasilkan pola yang sama pada kelas bahaya moderat dan berbeda pada kelas bahaya rendah dan tinggi. Kelas bahaya tinggi paling nyata terlihat pada penggunaan Cara2 di setiap tahun yang berbeda. Kelas bahaya tinggi teridentifikasi di perkebunan teh Ciliwung dan Ciseureuh serta daerah Pasifangin dan Cikalongkulon.

Hasil pemetaan dengan prosedur berbeda menghasilkan pola yang berbeda. Cara1 menghasilkan kelas rendah dan moderat yang relatif sama dan stabil, sedangkan Cara3 menghasilkan kelas bahaya moderat yang luas dan kelas rendah yang relatif sempit. Cara2 menghasilkan pola yang berbeda dimana kelas rendah yang luas pada tahun 1981 digantikan kelas moderat yang luas pada tahun 1994. Kelas bahaya tinggi juga ditemukan paling luas.

\section{Kehandalan berbagai Metode Pemetaan}

Pengujian kehandalan cara pemetaan dan prosedur penarikan batas bahaya longsor yang diteliti dilakukan dengan mengecek kembali reliabilitas kelas bahaya yang dihasilkan dengan fakta longsoran. Dalam hal ini, kelas bahaya tinggi akan berkorelasi dengan jumlah longsoran yang banyak. Dengan cara ini diketahui bahwa prosedur standar mempunyai kehandalan yang relatif rendah karena menghasilkan kelas bahaya tinggi pada kerapatan longsoran yang relatif rendah (Gb. 4a). Sebaliknya, penarikan batas kelas berdasarkan pola data menurut prosedur alami menunjukkan kehandalan yang lebih tinggi (Gb. 4b). 
Dengan pengujian yang sama, Cara2 diketahui memberikan hasil terburuk karena menghasilkan kelas bahaya yang tinggi pada kerapatan longsoran terendah, disusul oleh Cara1 dan Cara3. Meskipun demikian, kecuali Cara1 untuk kondisi 1981, seluruh cara pemetaan yang diteliti menunjukkan hasil yang relatif benar. Dalam hal ini, kelas bahaya rendah diperoleh pada nilai kerapatan longsoran yang rendah dan sebaliknya.

Kehandalan cara pemetaan dan prosedur penarikan batas kelas yang diteliti juga diuji dalam hal keakuratannya memprediksi kejadian longsor. Dalam hal ini, cara dan prosedur yang menghasilkan peta bahaya longsoran terbaik pada kondisi 1981 diharapkan akan memberikan prediksi kejadian longsoran pada kondisi 1994 yang akurat pula. Artinya, dari daerah dengan kelas bahaya rendah pada 1981 diharapkan akan diperoleh prediksi kejadian longsoran yang tergolong rendah pula pada 1994. Dengan cara ini, Cara2 dan Cara3 dengan prosedur penarikan batas kelas bahaya longsoran menurut pola data atau kurva grafik kumulatif secara alami diketahui memberikan hasil paling akurat (Gambar 5).
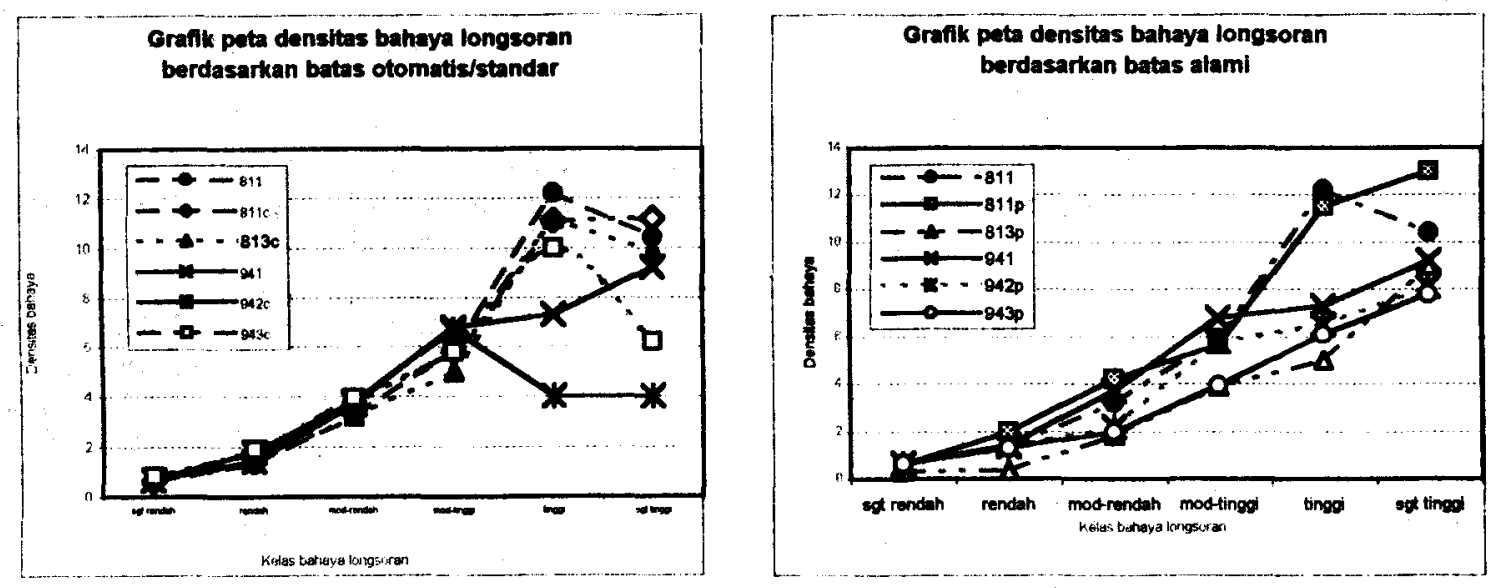

Gambar 4. Perbandingan hasil ketiga cara pemetaan dengan prosedur penarikan batas kelas (a) secara standar dan (b) berdasarkan pola data

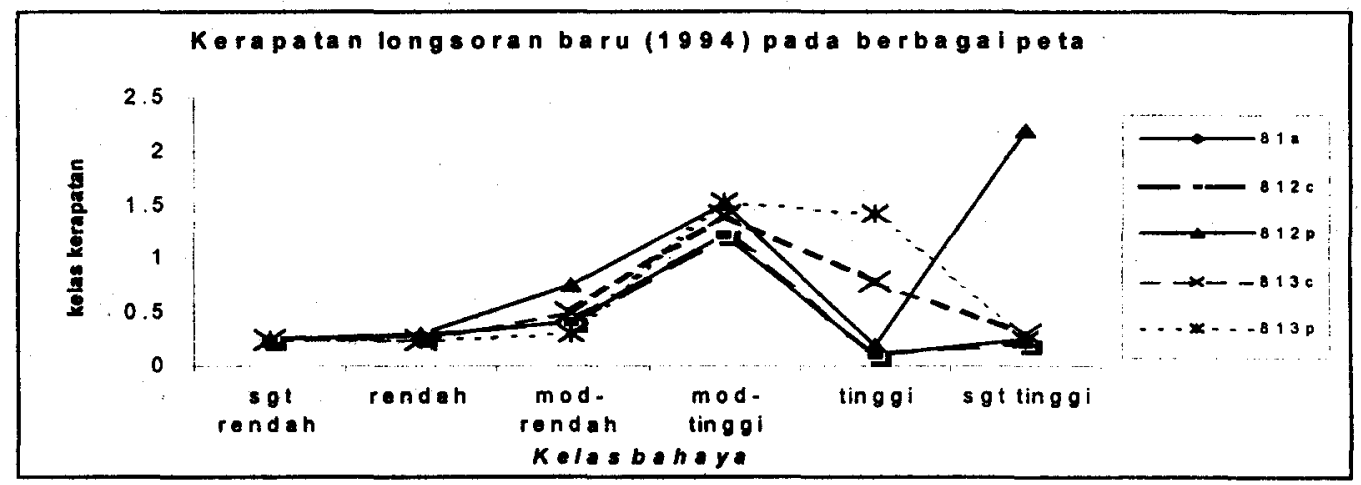

Gambar 5. Perbandingan hasil pemetaan tahun 1981 dengan cara berbeda yang diuji berdasarkan data longsoran tahun 1994 
KESIMPULAN DAN SARAN

\section{Kesimpulan}

1. Penggunaan prosedur alami yang mempertimbangan kemiringan kurva padá grafik kumulatif dalam penentuan batas klasifikasi kelas bahaya longsoran menghasilkan peta yang lebih relevan dengan fakta di lapangan dibandingkan prosedur standar.

2. Pertimbangan terhadap unsur umur dan aktivitas longsoran dalam pemetaan dan klasifikasi bahaya longsoran sangat menentukan keakuratan hasil akhir peta yang diperoleh. Dengan hanya mempertimbangkan umur longsoran, Cara2 menunjukkan kehandalan tertinggi dalam hal pemetaan, klasifikasi maupun prediksi kejadian longsoran pada periode berikutnya. Dengan Cara2 diperoleh peta bahaya longsoran tahun 1981 yang berhubungan kuat dengan peta tahun 1994. Cara1 menunjukkan hasil yang paling tidak relevan dengan fakta di lapangan.

3. Jika didukung bank data atribut yang baik, Cara3 yang memasukkan unsur umur dan aktivitas longsoran sebagai pertimbangan diduga akan memberikan hasil yang lebih baik. Kelemahan cara ini berkaitan dengan proses pengkonversian data raster ke vektor yang menyebabkan menyusutnya ukuran unit longsor sehingga tidak terekam dalam perhitungan kerapatan unit peta ketika ditumpangtindihkan.

4. Secara umum, pengaruh individu faktor penyebab terhadap munculnya kejadian longsoran di daerah studi telah diketahui dan relevan dengan fakta lapang maupun teori yang sudah berkembang, kecuali untuk daerah dengan tipe batuan induk marl-clay yang seharusnya paling rentan tetapi tidak demikian. Dalam hal ini, pengaruh interaksi antar berbagai faktor penyebab longsoran belum diketahui secara jelas.
Saran

1. Untuk tujuan pengamatan, pemetaan dan pemantauan fenomena longsoran, penggunaan fotoudara yang berkualitas sama untuk kondisi tahun berbeda perlu terus dikembangkan karena dari penelitian ini diketahui sangat berperan dalam menentukan kualitas hasil klasifikasi, pemetaan dan prediksi.

2. Pengaruh kombinasi berbagai faktor penyebab longsoran seperti tipe tanah, penggunaan lahan (vegetasi), bahan induk dll perlu diteliti lebih lanjut.

\section{DAFTAR PUSTAKA}

Aronoff, S. 1993. Geographic Information System: A Management Perspective WDL Publi. Ottawa, Canada.

Lillesand, T.M. and R.W. Kiefer. 1994. Remote Sensing and Image Interpretation. 3rd Ed. John Wiley and Sons, Madison, Wisconsin, USA.

Rengers, N. and R. Soeters. 1993. Satellite Remote Sensing and GIS for Landslide Hazard. Proc. Int. Symp. Operationalization of RS. Vol 9. ITC Enschede.

Sidle, R.C., A.J. Pearce, and C.L. O'Loughlin. 1985. Hillslope Stability and Landuse. American Geophysical Union, Washington, USA.

Greenway, R.J. 1987. Vegetation and slope stability in M.G. Anderson and K.S. Richards (Eds.): Slope Stability, Geotechnical Engineering and Geomorphology. John Wiley \& Sons, Chichester, NY, USA.

Gupta, A. 1993. The changing geomorphology of humid tropics. Geomorphology 7:165-186. Elsevier Publ. B.V. Amsterdam.

Varnes, D.J. 1984. Landslide Hazard Zonation: A Review of Principles and Practices. Unesco, Paris. 
PERBANDINGAN HASIL PETA BAHAYA LONGSORAN 1981 DAN 1994 DARI TIGA CARA

DENGAN BATAS KELAS MENURUT PROSEDUR STANDAR
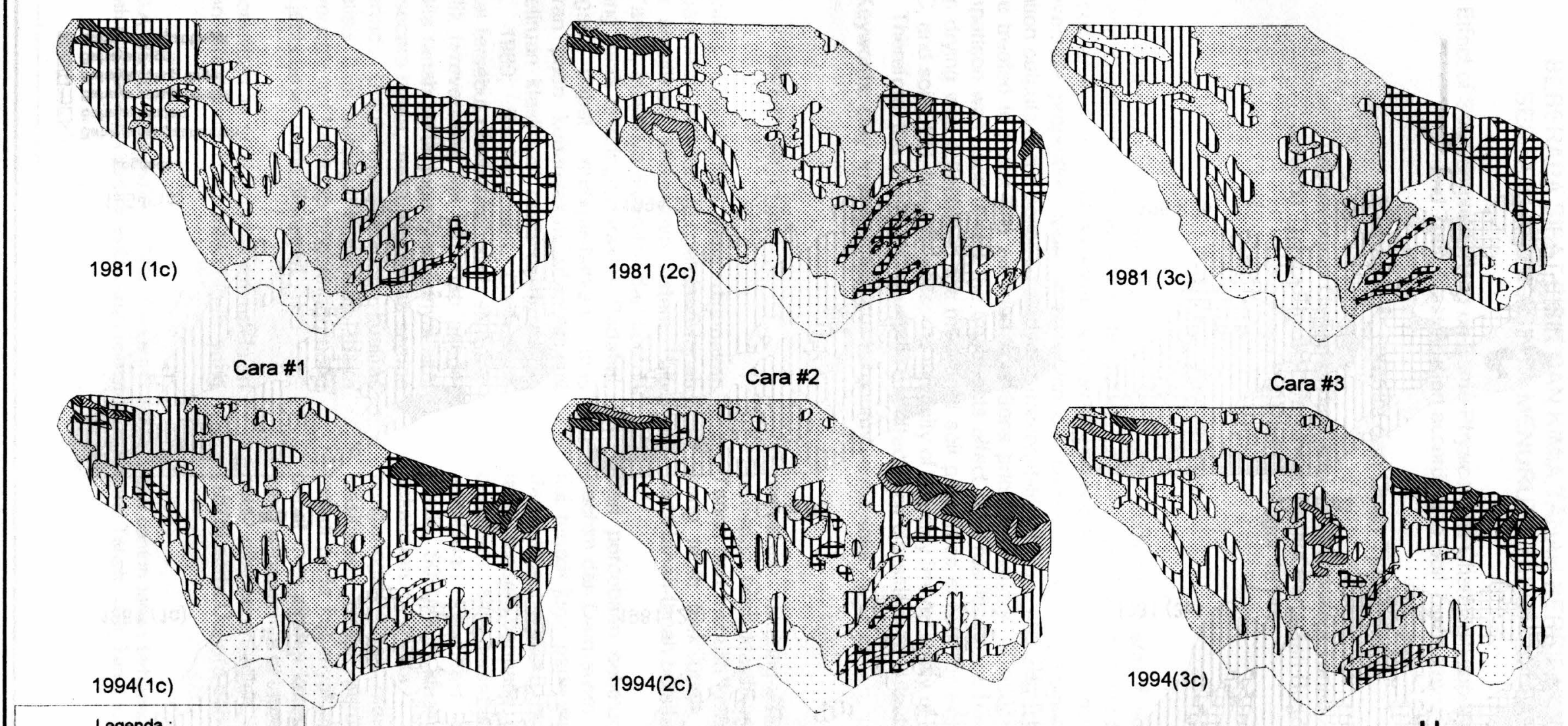

Legenda :

Bahaya sangat rendah

Bahaya rendah

III Bahaya cukup rendah

Bahaya cukup tingg

Bahaya tinggi

Bahaya sangat tinggi 


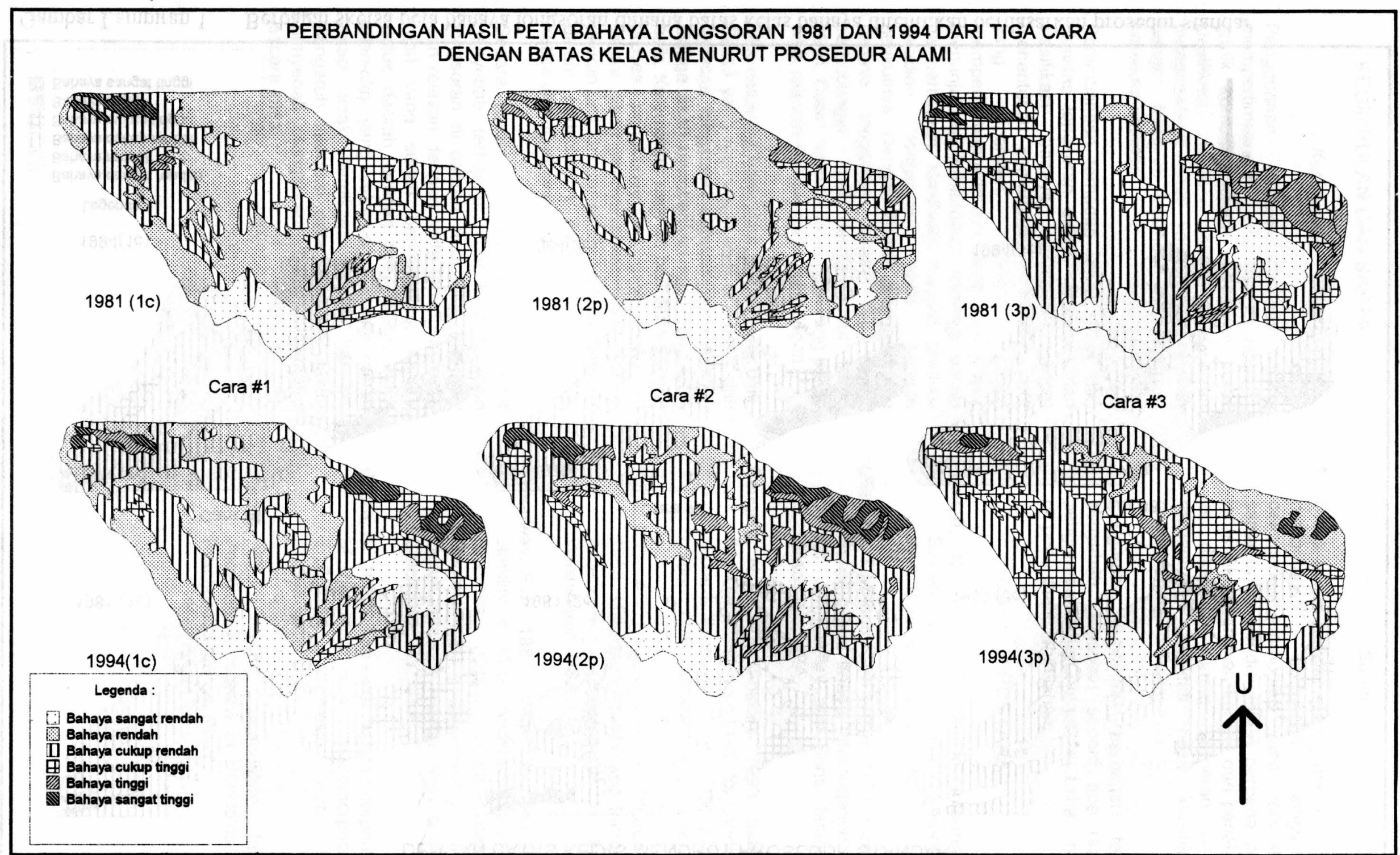

Gambar Lampiran 2. Berbagai sketsa peta bahaya longsoran dimana batas kelas bahaya ditentukan berdasarkan prosedur alami 